See discussions, stats, and author profiles for this publication at: https://www.researchgate.net/publication/322419390

\title{
Geographies of Lifelong Learning and the Knowledge Economy
}

Chapter · January 2018

Dol: $10.2307 / \mathrm{j}$. .tt1xp3nf1.9

CITATION

1

2 authors:

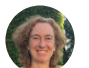

Katharyne Mitchell

University of California, Santa Cruz

94 PUBLICATIONS 2,844 CITATIONS

SEE PROFILE

Some of the authors of this publication are also working on these related projects:

The Critique of Strategic Management View project

Project Critical humanitarianism View project
READS

27

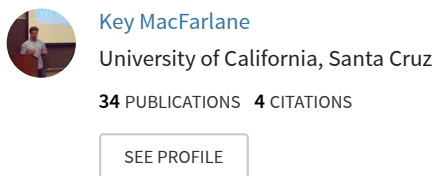




\section{Pluto Press}

\section{Chapter Title: Geographies of Lifelong Learning and the Knowledge Economy}

Book Title: Making Workers

Book Subtitle: Radical Geographies of Education

Book Author(s): Katharyne Mitchell

Published by: Pluto Press. (2018)

Stable URL: https://www.jstor.org/stable/j.ctt1xp3nf1.9

JSTOR is a not-for-profit service that helps scholars, researchers, and students discover, use, and build upon a wide range of content in a trusted digital archive. We use information technology and tools to increase productivity and facilitate new forms of scholarship. For more information about JSTOR, please contact support@jstor.org.

Your use of the JSTOR archive indicates your acceptance of the Terms \& Conditions of Use, available at https://about.jstor.org/terms 


\section{4 \\ Geographies of Lifelong Learning and the Knowledge Economy}

Lifelong learning is traditionally defined as learning that continues throughout one's life and that encompasses both traditional schooling and informal venues and practices. It is a form of learning most frequently undertaken by adults to improve their skills and knowledge so as to gain better employment opportunities. In this view, lifelong learning is a wonderful opportunity, one voluntarily engaged in and frequently enjoyed, leading to personal fulfillment as well as greater professional development and the chance to improve one's life chances.

Lifelong learning can indeed be these things for individual actors, but as a governing concept and set of institutional practices it has broader, frequently negative repercussions for workers and for society as a whole. As discussed in the preceding chapters, the perceived skills necessary for contemporary employment success have shifted over the last few decades. These changes indicate the growth of new global divisions of labor, neoliberal rationalities of governance, and a related demand for the constant retraining, redevelopment, and redeployment of human capital worldwide. In this chapter I am interested in how the concept of lifelong learning was deployed by state actors at different scales of governance, including the supranational European Union (EU), to shift responsibility for retraining to the individual. I show further how the policies and institutions formed on the basis of this concept have worked to secure a capitalist process of exploitation that benefits a global elite far more than individual workers.

Lifelong learning plays a role in the production of space, not just as an abstract governing principle but also as a diverse set of practices and institutions that has developed and transformed over time and scale to address the crises of global capitalism. The concept of lifelong learning was first promoted in the early 1970 s by intergovernmental organizations such as the United Nations Educational, Scientific and Cultural Organization (UNESCO) and the Organization for Economic 
Cooperation and Development (OECD). Similar in some ways to the formulations of multicultural education during the same time period, many of these organizations introduced ideals of democratic learning and personal development. These liberal ideals of individual freedom and growth were, at the same time, always linked with assumptions of economic necessity.

With the advance of neoliberal globalization in the 1990s, however, lifelong learning emerged in more narrowly strategic forms in the policy frameworks of the United States, Canada, and the EU. Neoliberal policies during this latter era worked to orchestrate personal development within the increasingly flexible processes of global capitalism, placing both within the rhythm of a personal life that must be fulfilled. Such an orchestration produced certain spaces-captured in notions such as the "learning society" and "creative city" - in which citizens were expected to take responsibility for their own human capital development as flexible entrepreneurs. For the majority of the population, however, this process led primarily to their own deskilling. Moreover, not only did lifelong learning strategies promote the standardization and homogenization of educational skills, and thus the abstraction and interchangeability of labor, but they were also bound up with the production of a so-called learning society that demanded increasing levels of external management. In the following sections I look at some of the ramifications of these processes on workers and systems of education.

\section{Freedom and Necessity in Lifelong Learning}

It is no accident that the concept of lifelong learning first gained traction in the early 1970s. As noted earlier, this was a time when a new international division of labor was emerging and manufacturing jobs in core countries began moving offshore in greater numbers. Suddenly, large swaths of the workforce became obsolete, possessing skills that were no longer marketable within their national borders. These were primarily blue-collar jobs in heavy industries such as steel and automobile manufacturing, as well as in mining and other forms of resource extraction.

Traditional forms of education-those that ended somewhere in the individual's youth-seemed outdated against this backdrop, failing to meet the demands of a new global economy. ${ }^{1}$ The concept of lifelong learning emerged within policy circles and academia as a potential solution to this problem. The underlying assumption throughout this 
period was that extending education into adulthood could provide a way of retraining workers in core countries, giving them the skills needed to compete in a rapidly globalizing economy.

Despite this clear economic imperative, however, during the 1970 s lifelong learning was generally framed as a basic human right. This orientation was manifested in the Third International Conference on Adult Education, held in Tokyo in 1972, where it was declared that "the right of individuals to education, their right to learn and to go on learning, is to be considered on the same basis as their other fundamental rights." ${ }^{2}$ This moment marked a strong reinterpretation of the right to education as originally stated in the UN's 1948 Universal Declaration of Human Rights. It seemed that the newly conceptualized human right was no longer ascribed to a time-bound notion of schooling connected to the possibilities of immediate employment, but rather to a process of learning and human development that continued through a person's lifetime.

Owing to the stronger narrative of freedom and human rights in the documents of this era, some scholars argued that the concept and practices of lifelong learning changed radically from this early period vis-à-vis its more contemporary iterations. In this view, the earlier period of lifelong learning encouraged and enabled autonomous individual choices and personal development, but these opportunities were no longer viable in later years, and lifelong learning became more about necessity and economic survival in a rapidly transforming global economy. ${ }^{3}$ This scholarly analysis rested on abstract liberal assumptions about the potential for great individual opportunity and freedom in the Fordist period, which underplayed the importance of ongoing structuring forces in economy and society, including differences of race, gender, and age, as well as class position.

A more nuanced analysis situates lifelong learning as a concept and set of practices always implemented within capitalist regimes of accumulation, yet shifting in various ways in response to historical and geographical context. Further, it encompasses variations in identity and social position that are bound up in these broader social and economic forces. The most important of the changes affecting these types of educational processes today are the contemporary forces of globalization and the rise of flexible regimes of accumulation and new spatial divisions of labor. Thus in looking at both the narrative and practices of lifelong learning it is critical to examine the underpinning connections 
of lifelong learning to broader capitalist dynamics, including processes of commoditization, whereby learning is turned into a possession that can be bought and sold on the marketplace. But at the same time it is equally important to tease out the variations, divergences, and contradictions that occur as lifelong learning is introduced to different groups and taken up in different times and places.

The merging of both freedom and necessity in early lifelong learning formulations is evident in some of the first policy documents published by UNESCO and the OECD. ${ }^{4}$ On the one hand, UNESCO and the OECD differed greatly in their approaches. While UNESCO emphasized lifelong learning as a basic human right, the OECD was more concerned with lifelong learning as an economic fix. These rationales were not incompatible, however. On the contrary, when reading the UNESCO and OECD documents side by side, what becomes evident is that the concept of lifelong learning provided a site for joining, and thereby legitimizing, the flexibilization of labor with certain liberal-humanist conceptions of personal development. While the introduction and implementation of lifelong learning has varied in tone and emphasis over time, this basic articulation remains a core feature.

In the OECD document, lifelong learning was endorsed as a way of generating the occupational flexibility necessary to succeed in an economy with constant technological developments and new labor demands. It was imagined that through lifelong learning programs, the unemployed could not only acquire more marketable skills "but also become a manpower reserve on which the various countries' economies could draw."' Lifelong learning was thus seen as a way of producing an educated "reserve army of labor" in a period of economic change. Radical critiques of capitalism have noted how this type of reserve army can benefit capitalist economies because it provides an easily exploitable pool of labor, which tends to drive down the average cost of wages for everyone. ${ }^{6}$

What is interesting about the OECD report is how such large-scale economic imperatives were paired with the language of individual choice. Despite the strong emphasis on economic development, the report's authors indicated that lifelong learning would only be successful when conceived and opted into as a process that also benefited individuals. This trend of conceptually binding and blurring economic growth with personal satisfaction and a sense of individual value is one that has continued through the historical trajectory of lifelong learning. In the 
following section I examine how these intersections were implemented in national policies, which have similarly tied personal growth to issues of employability and economic development.

\section{The Boom Years: Lifelong Learning in the 1990s}

It was not until the late 1990s in the United Kingdom, the United States, and Canada, that lifelong learning reached its peak popularity as educational policy. These years saw a flood of policy documents and reports calling for lifelong learning at both national and supranational scales. In Europe, the concept became a key policy agenda in 1996 after the European Commission (EC) christened that year as the European Year of Lifelong Learning. ${ }^{7}$ In the United Kingdom, in particular, lifelong learning was an important component of New Labour's education policy. The government's first major statement on it came out in 1998, in an enthusiastic report entitled "The Learning Age: A Renaissance for a New Britain."8 Similar eagerness was found in North America, where the US Congress ratified the Lifelong Learning Credit (LLC) in 1997 and the Canadian government rolled out the Lifelong Learning Plan (LLP) in the federal budget for $1998 .^{9}$

Consistent across these policy documents was the view of education as a strategic economic investment. This was typical of the kind of "third way" politics popular in these countries at the time, under the leadership of Tony Blair in the United Kingdom, Bill Clinton in the United States, and Jean Chrétien in Canada. While third-way politics played out differently in each of these countries, there was a similar emphasis on investments in personal development, responsibility, and equal opportunity through market-based solutions rather than via centralized government programs. The most infamous example of this was in the move from welfare to workfare under President Clinton.

The shift in the social safety net from government provision to one of individual responsibility was particularly evident in education. Blair's position was manifested most clearly in "The Learning Age, a government report in which lifelong learning was held up as a tool for developing "the skills, knowledge and understanding that are essential for employability and fulfilment." ${ }^{10}$ Notions of personal growth and well-being were repeatedly and insistently connected with economic strategies, inseparable from the essential ability to sell one's labor on the global market. Thus, under the aegis of New Labour's policies on 
lifelong learning, personal fulfillment and employability came to mean the same thing. Moreover, the necessity to opt in to this neoliberal nexus of human capital development-or suffer the consequences-was quite explicit.

In the United States and Canada during the same time period, lifelong learning policy was also tied to personal growth and individual income set within the framework of the new global economy. Canada's LLP, for instance, was one of several Canadian federal policies on education and training implemented with the explicit intention of developing a high-skilled knowledge economy. ${ }^{11}$ It allowed individuals to withdraw money from their registered retirement savings plans to enroll in higher education or training programs for at least three months. The ways in which these loan-based policies were set up urged individuals formerly disconnected or excluded from the global economy to reskill themselves and become responsible entrepreneurial actors in the new era. ${ }^{12}$

Canada's LLP provides an excellent example of neoliberal governance, wherein policies promoted at the state level devolve the responsibility for successful labor market access and employment to the individual. In comparison with the preceding Fordist regime, where the state was involved in and responsible for producing the conditions for full employment, both the risk and the responsibility of employment now fell completely to the individual worker. This worker, moreover, had to understand the optimal conditions for employment, prepare himself or herself for these opportunities-even prospective ones-and pay for the possibility of success out of retirement accounts, thus effectively withdrawing on his/her own future. ${ }^{13}$ The individual thus became financially indebted to his or her future self, and encouraged to act and self-manage in ways that ensured that educational investments actually paid off economically. Indeed, the government's explicit goal for this loan was to enable individuals to increase their earning potential, framing education solely as a means of access to future global marketability.

The LLC in the United States worked a bit differently, but maintained a similar third-way politics of individual responsibility. Rather than withdrawing money from a retirement fund, the LLC provided students with a nonrefundable tax credit for postsecondary education expenses. The LLC was part of a larger overhaul of the way that government financed higher education, and included other programs such as the Hope Scholarship Credit (later replaced by the American Opportunity Tax Credit), an expansion of savings plans such as education IRAs 
(individual retirement accounts), and student loan interest deductions. These changes occurred at both the federal and state level in the United States throughout the 1990s, amidst rising tuition rates, reduced funding for public institutions of higher learning, and an increasingly inadequate supply of direct grants for student aid. ${ }^{14}$

The LLC and Hope Scholarship, the largest of these education initiatives, represented a shift away from needs-based federal programs. Tied to tax liability, these programs offered no direct scholarships to pay for the rising costs of tuition. Lower income families had to resort to other means of paying the upfront costs of college, such as taking out loans. Using the tax system to subsidize higher education thus worked to indirectly shift responsibility from government services onto the individual to pay for his or her own education. At the same time, for those who received tax credits, the savings appeared less as a free welfare handout, and more as a reward for "good behavior" - in the sense of being employed (having a taxable income) and choosing to invest in education or lifelong learning. Indirectly, therefore, the individual was nudged into and made responsible within certain normative value systems-systems that aligned with the social reproduction of capitalist relations.

In practice, this type of individual responsibilization did not play out evenly across social divisions of class, gender, race, and age. In Canada, for example, while the LLP and similar federal education policies claimed to enable equal access, in fact they continued to exclude the most marginalized segments of the population. Individuals could withdraw from their registered retirement savings plans in order to improve their earning potential only if they had already earned enough to contribute to a retirement account in the first place. ${ }^{15}$ As such, the LLP served to help those already relatively well off. Similar arguments were made about the LLC in the United States, which was explicitly conceived to aid middle-class Americans. Most low-income students had no tax liability and were therefore not eligible to receive the LLC tax credit.

Although there were other federal programs to assist low-income students such as the Pell Grant in the United States, it is nonetheless significant that federal policy on lifelong learning in both countries offered minimal benefits to those out of work or precariously employed. In some ways, policies such as the LLC and LLP worked to actively produce this precarity, insofar as the solutions offered were limited to the market mechanisms that produced these vulnerabilities in the first place. Through the economization of education and personal 
development, other potential forms of addressing insecurity-for example, through resource distribution or mutual aid-were ignored or deemed financially imprudent.

\section{From Integration to Responsibilization in the $E U$}

In the preceding section I investigated some of the ways that state policies associated with lifelong learning were introduced in the United States, Canada, and the United Kingdom at the turn of the twenty-first century. Many of these emphases can also be seen in the EU, but there were some interesting differences as well. In some ways similar to the postwar discourse of multiculturalism in England, the earlier iterations of lifelong learning in the EU contained a stronger narrative of social inclusion and the value of cultural diversity with respect to minority integration into European society. But this emphasis began to erode in the context of neoliberal pressures towards strategic learning for the global knowledge economy.

Although neoliberal ideas and actors started to dominate policymaking in the 1990s, they operated in tension with more interventionist programs initiated in the earlier era. Internal divisions and struggles over these programs were particularly evident in the realm of social policy and the politics of European social cohesion. In the sphere of education and training, the EU's primary role was to support its member states and to address what were considered to be common challenges for all nations. These included the ageing of the population, the changing skills needed for the European workforce as a whole, technological transformations, and global competition. With the broad shift towards more laissez-faire practices and beliefs, education became a critical site of struggle over the funding priorities and institutional policies associated with these common challenges. Lifelong learning was one of the many mandates caught up in this struggle, as an interest in diversity and social cohesion slowly lost ground to a more economistic logic of governance.

The shift in the EU's educational emphasis was particularly evident in the policy orientation of the 1999 Treaty of Amsterdam, among other treaties of that time period. Programs promoting state intervention, including attempts to encourage cohesive European social communities, began to lose ground to a more economistic emphasis following the treaty's passage. Rather than the social control of labor through the management of difference, EU programs started to focus more on 
strategies of skills-based training designed to forge all students (both native-born and immigrant) into European citizens via an increasingly cross-border intra-EU labor market.

Lifelong learning was a prominent feature in the so-called "employment chapter" of the Amsterdam Treaty. The employment chapter called on member states to coordinate their employment policy with respect to four common pillars: employability, entrepreneurship, adaptability, and equal opportunities. The type of employment that was envisioned in the treaty was flexible employment, and the laborers who were to provide the workforce were required to be adaptable and entrepreneurial if they expected to obtain and retain jobs. This emphasis on workers' employability rather than workplace conditions represented a significant change in EU policy. According to one labor historian, the policy action areas of the employment chapter "represent[ed] a major shift in social policy" away from universal labor mandates and standards and toward a vision of employment as the key to maintaining the European social model. ${ }^{16}$

In this vision, lifelong learning was explicitly linked with the promotion of a skilled and adaptable labor force for the new, so-called "Europe of knowledge." In EC policy documents of this time period the necessity of constant personal mobilization, or what was then termed "updating," was a frequent refrain in reference to lifelong learning, and was inevitably linked with the employment requirements of a rapidly changing world. Further, successful employment was implicitly associated with successful citizenship. The following quote, from the 1997 EC document, "Towards a Europe of Knowledge," was one of the first discussions of the new strategies for education and training in general, and of lifelong learning in particular, that was envisioned for the EC's policy agenda of 2000-2006:

Real wealth creation will henceforth be linked to the production and dissemination of knowledge and will depend first and foremost on our efforts in the field of research, education and training and on our capacity to promote innovation. This is why we must fashion a veritable "Europe of knowledge." This process is directly linked to the aim of developing lifelong learning which the Union has set itself and which has been incorporated into the Amsterdam Treaty, expressing the determination of the Union to promote the highest level of knowledge for its people through broad access to education and its permanent updating. ${ }^{17}$ 
This utilitarian vision of lifelong learning as linked with wealth creation and employability was advanced further by the EU's education commissioner, Viviane Reding, in 2000 and 2001. In the policy agenda of this period there was a clear effort to tie together the commission Directorate of Education and Culture with the Directorate of Employment and Social Affairs. The skills-based, vocational focus of this cooperative strategy was made explicit in related documents and speeches. For example, Anna Diamantopoulou, the commissioner for employment and social affairs, said:

Skill and competence enhancement in the new economy in Europe requires that the policy emphasis is shifted towards increasing investment in human capital and in raising participation in education and training throughout working life. To keep pace with developments in technology, globalisation, population ageing and new business practices, particular attention should be given to workplace training, an important dimension of our strategy for Lifelong Learning. ${ }^{18}$

In March 2000, the Lisbon meeting of the European Council confirmed lifelong learning as a foundational component of the European social model. Employment was a key agenda item of the Lisbon meeting, as was the objective of shaping a new Europe and becoming "the most competitive and dynamic knowledge-based economy in the world." ${ }^{19}$ As a result of the Lisbon recommendations, lifelong learning was allocated significant funding for the period 2000-2006 from the European Social Fund and was confirmed as a "basic component of the European Social Model." ${ }^{20}$

In the speeches and documents associated with the Lisbon meeting, perpetual mobilization (formation permanente) was projected as constant, inevitable, and ultimately beneficial for society. The goal of "shaping a new Europe" focused on the importance of the transition to the knowledge economy and on the role of education and training in constituting a new dynamic and competitive European labor force. In this vision the challenge of reformation and retraining was devolved from the responsibility of the state to the agency of individuals, who were expected to choose personally effective learning strategies.

In the rhetoric of globalization, competition, and lifelong learning of that time period there was a strong underlying push for constant personal mobilization and entrepreneurial behavior on the part of individuals, 
while at the same time the many structural and institutional constraints to achieving these goals were obscured. Further, the inexorable emphasis on the individual and on his or her educational choices constructed rational, atomized agents responsible for their own life paths in lieu of groups or classes experiencing collective dislocation as the result of widespread socioeconomic restructuring under the processes of neoliberal globalization. This accompanied a more general abdication of responsibilities in providing truly viable economic opportunities for workers and/or for the harmonious integration of immigrants and minorities into European society.

Further, the original personal and social development emphasis of lifelong learning as detailed in earlier documents from the 1970 s was relegated to a minor rhetorical key. Community funds for lifelong learning went primarily into workplace retraining programs rather than into curricula emphasizing social or civic education such as the study of culture, comparative democracy, or systems of government. Thus, with the transformation of lifelong learning, European social cohesion became advanced more through the formation of a flexible and mobile cross-border labor force than through the notion of personal development and the constitution of democratic participants in society.

In all of these transformations there was a demonstrable effort by elites to shape Europe into the most premier knowledge economy in the world. In EU programs and discourses of the time one can see attempts to construct a fast-paced, mobile, and interchangeable laborer for this knowledge venue. Earlier concerns about the importance of social cohesion, including the emphasis on achieving diversity as beneficial for civic life and for the development of a European community, were replaced or accompanied with economistic assumptions about individual human capital. Moreover, it became the individual's responsibility to integrate effectively. If he or she did not, it was projected as an issue of individual choice rather than the failure of the egalitarian claims of liberalism.

These transformations were broadly linked with macroeconomic shifts relating to late-twentieth-century systems of flexible accumulation and the rise of neoliberalism as a political philosophy of governance. Indeed, the educational directives of the EU during this time did not just line up in accordance with these broader shifts but were in fact key mechanisms in reconstructing governance structures more widely. As the EU expanded through the early 2000 s it began to take on a more productive, and some argue greater imperial role in shaping policy, 
disciplining member states, and forming a European educational space that served as a "division of the neoliberal army." ${ }^{21}$

The educational strategies of this time, as Susan Robertson has noted, began to point towards a European project and vision of global leadership in the production of higher learning and knowledge in the European interest. ${ }^{22}$ Knowledge, in this image of the future-for both Europeans and North Americans - required not just the cooperation of choice-making and entrepreneurial individuals and learners, but also the spaces and managerial experts of a brave new society.

\section{Spaces of the Knowledge Economy, Creative Cities, and the New Managerial Elite}

When it first appeared in policy and academic discourse, lifelong learning was often coupled with the concepts of the learning society or the knowledge economy. All of these concepts emerged around the same time from scholars in the fields of education and management. These discourses reinforced a mythology that treated knowledge as a social and economic panacea. At the heart of this mythology was the figure of the knowledge worker. Peter Drucker, who coined the term in the 1950s, defined knowledge workers as "accountants, engineers, social workers, nurses, computer experts of all kinds, teachers and researchers," or, more broadly, people "who are paid for putting knowledge to work rather than brawn or manual skill." ${ }^{23}$

In Europe, the lifelong education of knowledge workers and the construction of the so-called knowledge economy could be best conceptualized as a space for new kinds of market opportunities. Both the language and the policies of lifelong learning and the knowledge economy carved out a terrain in which education and work were yoked together in a complex construction of personal value and human capital development, national and transnational community, and territory. This agglomeration provided multiple spaces for capital accumulation.

In the United States, the mythos of knowledge work was grafted onto popular imaginations of urban space through concepts such as the creative city, first pitched in the late 1980s. More recent buzzwords have included "smart city," "learning city," "knowledge city," and "resilient city." The creative city was first discussed in Richard Florida's famous thesis about the rise of the creative class. ${ }^{24}$ Florida argued that in the context of deindustrialization and the decline of manufacturing in core 
countries, knowledge workers were the emergent demographic critical for postindustrial cities to survive (rather than the older demographic segment appropriate for older manufacturing-based economies).

For Florida, the creative class in the United States was an increasingly important and valuable subsection of the workforce. It included a "super-creative core" of occupations focusing on the creative process and problem solving, as well as a group of creative professionals consisting of knowledge-based workers more generally. In the contemporary global economy, according to Florida, this class acted as a major driver of economic growth through its ability to innovate, as well as its ability to be flexible and adapt to changing economic needs. As a result, cities should make every effort to attract these workers. Florida argued that creative types were particularly drawn to cities that fostered cultural values of diversity, openness, and tolerance-in the business realm but also in terms of an artistic and bohemian scene.

Placing such a premium on knowledge work and creativity recast the city as a marketing hub for the promotion of an edgy brand or lifestyle, one that it pitted against other cities in the competition over so-called creative talent. This culture industry was, however, geared towards a very small segment of the working population. Not only did certain cities lose out in the scramble for creative labor, but the elite utopia of the creative city - as it played out in the policies, investment strategies, and development projects installed for attracting and retaining the creative class-tended to intensify urban inequalities along lines of class, gender, and race.

Florida's ideas were extremely persuasive to those urban politicians and institutions struggling to fashion their cities in ways attractive to international capital investment. Creating an urban revival by courting the "hip and cool" was a relatively cheap strategy, and one that urban elites embraced wholeheartedly in the early 200os. But, as Jamie Peck has shown, the main benefits of this "good business climate" strategyone of appealing to the most creative members of society through the provision of things like bike lanes, attractive downtown housing, and gay-friendly policies-has flowed primarily to real estate developers and members of the urban elite. It has neither galvanized urban economies nor trickled down to lower-wage workers, as initially conceptualized. ${ }^{25}$ Indeed, the strategy actively worked against the interests of the poor and lower-income residents of cities. It often intensified gentrification processes and discouraged the intervention of local governments in 
providing social services and affordable housing to the insufficiently flexible or "non-creative" members of society.

The global promotion of the knowledge economy and its spatial manifestation in creative cities or a "Europe of tomorrow" policy sphere had widespread and lingering effects beyond economic exclusion. Cultural assumptions about personal worth and the value of certain kinds of work were (and remain) deeply affected by this discourse. As Oakley and O'Brien have noted:

The workforce of these industries, the "creative class" celebrated by policymakers and depicted as key to economic growth ... is seen to be endowed with particular characteristics-flexibility, adaptability, creativity and even "tolerance"-which are themselves often the product of stratification. To be lacking in these qualities is to be designated as not having value or worth in society. ${ }^{26}$

Oakley and O'Brien demonstrated further how these webs of belief about labor and value played out in schools and in higher education admissions, as well as in cultural labor markets. Moreover, even as admissions directors and urban policy makers made value judgments about worthy students and valued workers, so too did the students and workers themselves.

The effort to become a valued member of society through higher education or lifelong learning, or otherwise joining the ranks of the knowledge economy, is now a global phenomenon, as discussed in Part I. But the success of this effort remains stratified not just by class and other axes of difference, but also by culture itself. In a vicious cycle, the spaces of the knowledge economy and the creative city are linked to certain characteristics of learning, and these in turn are associated with forms of cultural capital attributed to the (largely white, primarily male) middle classes. Even when those of lower social class obtain higher degrees or certificates of advanced learning, they are comparatively disadvantaged in mobilizing these experiences and forms of knowledge to access the labor market. Thus the desired cultural attributes of the knowledge economy and creative city workers-such as creativity and tolerance-continue to advantage the elite even as its promoters suggest the opposite.

Lifelong learning poses as an important path to individual autonomy and freedom as well as economic stability for workers, especially for 
those who have been displaced by economic restructuring. Yet the same blockages to social mobility that are encountered in more traditional educational pathways remain in place. In this sense, the promotion of creativity, flexibility, and tolerance as necessary characteristics of the "new economy" worker can be seen as something of a red herring-examples of a larger process of depoliticization wherein, despite the liberal patina of change, underlying problems of inequality, immobility, and injustice remain intact. Against the backdrop of the new economy, the latter appear as the products of intolerance or inflexibility. They become issues of psychological or cultural difference-intolerant ways of life-rather than structural imbalances demanding concrete political action. ${ }^{27}$

Whatever its good intentions, the uncritical demand for increasing worker creativity and tolerance fails to acknowledge the historical and geographic exclusions that allow for this new kind of worker to emerge in the first place. Those unable to pick up the torch of flexibility-a single mother, an impoverished teen, a non-native speaker-are demonized as logjams in an otherwise progressive system.

Such paradoxical freedom is most evident in the way the production of knowledge workers has been coupled with an increased need for managing these "autonomous" workers. This is apparent in Drucker's writings on knowledge work. On the one hand, he emphasized how the worker was most productive when unsupervised: "He [sic] must direct, manage and motivate himself." ${ }^{28}$ Yet Drucker mentioned elsewhere that a knowledge society "requires ... that knowledge and the knowledge worker be managed productively." ${ }^{29}$

Drucker's ambivalence points to a deeper contradiction within capitalist accumulation, one that becomes very pronounced in a knowledge economy. This is the tension, noted by Marx, between the need to increase the level of cooperation between workers (to increase their productive power) and the need to control this cooperation (to orient it towards the aims of profit). In theory, by bringing workers together in new ways, cooperation produces the conditions for a collective power among labor and thus poses a potential threat to "the domination of power." ${ }^{30}$ It is in reaction to the threat of resistance that, for Marx, the role of the modern manager emerges and becomes necessary for continued accumulation - "the work of directing, superintending, and adjusting." ${ }^{31}$

Marx would have found this kind of managerial work even more imperative in a knowledge economy, where the ideal worker is presumably given a larger degree of freedom and autonomy as an entre- 
preneurial actor in the global market. On the one hand, the dissemination of knowledge as a commodity presupposes a new kind of management style-a form of governance-whereby the worker comes to manage himself or herself in line with the interests of efficiency, flexibility, and the creation of profit. This is a kind of dispossession by possession, in which the worker becomes nudged into norms of productivity through his or her acquisition of mythic "knowledge." Through the commoditization of education, getting ahead in the global economy means working on yourself, acquiring new skills when needed, learning to invest in what the market demands.

At the same time, in line with Marx's arguments about management, the knowledge economy demands external governance as well. Knowledge must be policed and shaped to fit the socket holes of profit. In the United States this is demonstrated by the explosive growth of the managerial and professional classes in recent decades.

The dissemination of "business knowledge" since the 1960 s is what Nigel Thrift called the "cultural circuit of capital." ${ }^{2}$ Within this cultural circuit-where individual knowledge and economic success become interchangeable concepts-managerial coercion appears natural. Against the linear narrative of consent replacing coercion in the workplace, the management literature on knowledge work suggests that external coercion remains, and even increases, as an important tool for aligning the goals of the worker with those of the firm.

What has changed, as Michael Burawoy has noted, is the extent to which coercion becomes naturalized within the firm and internalized within the individual. ${ }^{33}$ Rather than a separate force, coercion appears as the object of consent when the individual chooses to opt in to a system of rules. When knowledge is fetishized as an organizational principle within the firm, the ideal manager acquires the status of an all-knowing guru or visionary leader. It is in this way, as Antonio Gramsci recognized long ago, that knowledge becomes weaponized along class lines as "cultural hegemony." ${ }^{44}$ Today, the cultural hegemony of capital serves to empower a managerial class, an elite group of individuals given special access to and mobility across the contours of capitalism. 